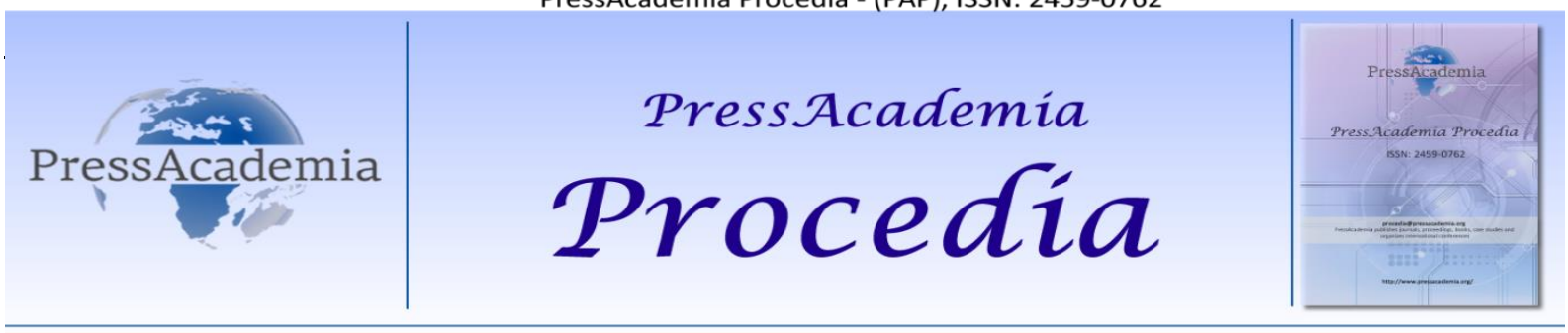

Global Business Research Congress (GBRC), May 24-25, 2017, Istanbul, Turkey.

\title{
THE EFFECT OF GLOBALIZATION OPERATIONS ON FINANCIAL FUNCTION
}

\author{
DOI: 10.17261/Pressacademia.2017.670 \\ PAP- GBRC-V.3-2017(97)-p.883-890
}

\author{
Murat Turgut \\ Nişantaşı Üniversitesi. murat.turgut@nisantasi.edu.tr
}

To cite this document

Turgut, M., (2017). The effect of globalization operations on financial function. PressAcademia Procedia (PAP), V.3, p.883-890.

Permemant link to this document: http://doi.org/10.17261/Pressacademia.2017.670

Copyright: Published by PressAcademia and limited licenced re-use rights only.

\begin{abstract}
Technological and scientific development which is the result of globalisation is forcing the current companies to change financially. Especially the rapid growth in informatics and communication, has not only increasednthe processing speed but aLso destroyed the importance of the consepts like time and place. This situation made the investors invest on the international markets and also reach international funds. Globalisation has amde radicalisation in companies' financial structure. It has now beeb obligatory for the companies to adapt the change And the ones which can not adapt to this change are thought to go down in this competitive market. Globalization, which is indexed to technological and scientific developments, has brought many radical changes in the field of economics as well as in many areas. In the process of globalization, new trends are emerging in national and international economic markets. New trends in the economy have affected businesses the most. When it is thought that increasing the influence of the globalization process day by day, the enterprises which are trying to maintain a closed economic structure by stopping the process in the environment of intense competition and interaction are deemed to have accepted to throw themselves out of economic life. In this point, it is very important for the enterprises targeting to succeed in the globalization process to apply the new techniques and approaches in the financial area. Because new trends brought together the concept and rules of financial globalization. The adaptation of new trends in national and international businesses is required in a competitive environment in which dynamic economies are adapting to the process. Globalization affects the whole of business functions because of having an open system. On the other hand, the fact that most of the decisions taken by the business are financial, makes the financial function more attractive. For this reason, it is necessary to take a holistic approach to business functions in a finance-oriented manner. Effective financial management practices need to be dealt with in order to achieve this.
\end{abstract}

Keywords: Globalization,Finance, financial Functions,Corporate Finance,International Finance

JEL Codes: A11,D21,D53

\section{GLOBALLEŞMENIN IŞLETMELERIN FINANSAL FONKSIYONU ÜZERINDEKi ETKISi}

\section{ÖZET}

Globalleşme süreci ile yaşanan teknolojik ve bilimsel gelişmeler günümüz işletmelerini finansal açıdan değişime zorlamaktadır. Özellikle bilişim ve iletişim alanında hızlı gelişim işlem hızını artırımanın yanından yer ve zaman gibi kavramlarında önemini ortadan kaldırmış̧ır. Bu durum yatıımcılara uluslararası piyasalara yatııı yapma veya işletmenin ulusal sınırlar dışındaki fonlara ulaşmasını kolaylaştırmıştır. Globalleşme ișletmelerin finansal yapılarında radikal değişimlere sebep olmaktadır. İșletmelerin değişim sürecine adapte olması zorunluluk haline gelmiş, ayak uyduramayan işletmelerin rekabet ortamında varlığını daha fazla sürdüremeyeceği de nihayetinde ortaya çıkmıştır. Teknolojik ve bilimsel gelișmelere endeksli olan globalleşme birçok alanda olduğu gibi ekonomi alanında da radikal değişimleri beraberinde getirmiştir. Globalleşme sürecinde ulusal ve uluslararası ekonomi piyasalarında yeni eğilimler ortaya çıkmaktadır. Ekonomi piyasalarında meydana gelen yeni eğilimler en çok işletmeleri etkilemiş̧tir. Globalleşme sürecinin etkisini her geçen gün arttırdığı düşünüldüğünde işletmelerin yoğun rekabet ve etkileşim ortamında sürecin karşısında durarak, kapalı bir ekonomik yapı sürdürmek isteyen işletmeler kendilerini ekonomik hayatın da dışına atmayı kabul etmiş sayılmaktadırlar. Bu noktada globalleşme sürecinde başarıı olmayı hedefleyen işletmelerin finansal alandaki yeni teknik ve yaklaşımları uygulamaları büyük önem taşımaktadır. Zira yeni eğilimler finansal globalleşme kavramını ve kurallarıı beraberinde getirmiştir. Dinamik yapıdaki ekonomilerin sürece adapte olması rekabet ortamında ulusal ve uluslararası işletmelerinde yeni eğilimlere adaptasyonunu gerekli kılmışıı. İşletmelerin açık bir sisteme sahip olmaları nedeniyle globalleşme işletme fonksiyonlarının tamamını etkilemektedir. Diğer taraftan işletmenin aldığı kararlarııı büyük kısmııın finansal nitelikte 
olması finans fonksiyonunu daha faza etkilemesine neden olmaktadır. Bu nedenle işletme fonksiyonlarının finans yönelimli bir şekilde bütüncül olarak ele alınması gerekmektedir. Bu durumun sağlanması içinde etkin finansal yönetim uygulamalarının hayata geçirilmesi gerekmektedir.

Anahtar Kelimeler: Globalleşme, finans, finansal fonksiyon, kurumsal finansman, uluslararası finans.

JEL Kodları: A11 ,D21, D53

\section{GiRiş}

21. yy itibari ile etkisi giderek daha fazla hissedilmeye başlanan bir değişim süreci içine girilmiştir. Söz konusu süreçte yeni eğilimler, yaklaşımlar, teknikler ortaya çıkmakta ve kullanım alanı bulmaktadır. Globalleşme süreciyle birlikte ülke ekonomileri üretim pazarları ve finans piyasaları, liberalleşme ve işbirliğinin arttığı bir yapıya dönüşmüştür. Bu gelişmeler neticesinde finansal globalleşme ve rekabet gücü gibi kavramlar ülke ve işletmeler açısından son derece önemli bir hal almıştır

Finansal globalleşme, ulusal finans piyasalarının birbirinden ayıran sınırların ortadan kalkması ve uluslararası piyasa hareketliliğinin farklı bir boyuta taşınmasını ifade etmektedir. 1980'lı yıllardan günümüze kadar olan süreçte finansal globalleşme ekonomik alanda görülen en önemli gelişimdir. Sınırların ortadan kalkması ile yaşanan hızlı etkileşim ve pazar ekonomisine geçiş süreci gibi faktörler ülke piyasalarının etkileyerek, piyasaların birbiri içine geçmesine neden olmuştur.

Finans piyasalarındaki globalleşme, piyasaların serbestleşmesiyle gelişen bir olgudur. Aynı zamanda ulusal para birimlerinin konvertibiliteye geçmesi, döviz kontrollerinin kaldırılması gibi unsurlarda finansal globalleşme sürecinde itici güç görevini görmüştür.

\section{GLOBALLEŞME TANIMI VE KAPSAMI}

Dünya hızlı bir gelişim dönemine girmiştir: globalleşme. Globalleşme ülkeler arasındaki sınırların ortadan kalmasına, yabancı semeye hareketliliğinin hız kazanmasına ve ülkelerin teknolojik ve bilimsel alanlarda birbirinden etkilenmesini sağlamıştır. Globalleşmenin kesin ve net bir tanımı olmamakla beraber etki alanındaki çeşitlilik farklı şekillerde tanımlanmasına yol açmaktadır.

Globalleşme Dicle'ye göre, ürün ve süreçlerin standart bir hal alması; sosyo-ekonomik farklılıkların ortadan kalması veya uluslararası işletmelerin denizaşırı ülkelerdeki tüketicinin ihtiyaç ve gereksinimlerini karşılayabilmesidir. Ayrıca globalleşmeyi, çok uluslu işletmelerin kontrol altında tuttuğu, yönlendirdiği ve denetlediği dünya pazarının meydana getirilmesi olarak da ifade etmek mümkündür (Dicle, 2000: 56-57).

Öymen'e göre globalleşme, salt ekonomik gelişmeler olmayıp aynı zamanda siyasi, sosyal, çevresel, kültürel ve hukuki boyutları olan bir süreçtir (Öymen, 2000: 27).

Çeken'e göre, globalleşme günümüzde politikadan ekonomiye, hukuktan insan haklarına kadar birçok alanda etkisini göstermektedir. Kültürel değişimde de önemli bir rol oynayan globalleşme, tüm bireyleri doğrudan etkileyen bir yapıdadır (Çeken, 2003: 5)

20. yy.'ın sonlarına doğru ağırlığını hissettirmeye başlayan globalleşme, dünya ülkelerini etkisi altına alarak sürece dâhil olmaya zorlamaktadır. Süreç eski değerleri egale ederek yerine daha yeni değerleri getirmiştir. Zira değişim sürecinin beraberinde getirdiği yeni değerleri benimsemeyen ülkeler globalleşme sürecinin dışında kalmakta ve gelişmelere ayak uyduramayarak geride kalabilmektedir. Bu süreçte ekonomik alanda dışa acılan ülkeler dünya piyasaları ile bütünleşmiş ve dünyada genelinde yaşanan entegrasyon süreci birçok ekonomik, sosyal ve kültürel etki yaratmıştır (Çeken, 2003: 8).

Buna göre globalleşme, dünya genelinde ürünlerin, finansal piyasaların, hizmetlerin, yatırımların, teknolojinin, bilimsel bilginin, düşüncelerin, eğitimin, politikanın, kültürün, değerlerin, çevresel ve toplumsal faktörlerin ülke sınırlarını aşarak bütünleşmesi ulusallaşması süreci şeklinde tanımlanabilmektedir. Görülmektedir ki globalleşme, ülkelere ekonomik, politik ve kültürel anlamda büyük değişimler yaşatmaktadır. Globalleşme süreciyle birlikte, sanayi iktisadı anlamda gelişmiş ülkelerden üçüncü dünya ülkelerine geçiş sürecine girmiş, finansal piyasalar çeşitli ülkelere yayılmış, bireylerin ülkeler arasındaki hareketliliği gibi gelişmeler kendini göstermiştir (Kutal, 1996: 55).

Bu bağlamda farklı alanları etkileyen globalleşme kavramı, insanları ve işletmeleri etkileyerek yeni bir dünya düzenin kurulmasına ve farklı değerlerin ortaya çıkmasına neden olmuştur. Bu nedenle gelişimleri yakalamak ve uyum sağlamak için kapalı ekonomilere sahip ülkeler dünyaya açılmaya başlamıştır. Zira günümüz şartlarında ülke ekonomilerinin kendi kendine yetemeyecek durumda oluşu dünyaya açılmayı zorunlu kılan diğer bir etken olarak görülmektedir. Bu durumun bilincinde olan ülkeler, ekonomilerini dışa açmaya, ticaretin, iş gücünün ve malların ve yatırımlarını serbestleşmesi için faaliyette bulunmaktadırlar. Kısaca uluslararası rekabettin ilkelerine göre hareket etmeye başlamaktadırlar. Bu sayede ekonomilerini 
dünya çapında rekabet edebilir bir hale getirmeyi amaçlarlar. Bu duruma bağlı olarak ekonomik globalleşme kavramı ortaya çıkmaktadır. Ekonomik globalleşme, ülke ekonomisinin dünya ekonomisi ile entegrasyonunun yani dünyanın tek bir pazar haline gelmesini ifade etmektedir. Bu noktada ülkeler arasındaki mal, sermaye ve emeğin karşılıklı etkileşimi sonucunda ülkeler arasındaki ekonomik ilişkiler artmakta ve ülkeler birbirine yakınlaşmaktadır.

\section{GLOBALLEŞMEYI ORTAYA ÇIKARAN NEDENLER}

Liberal eğilimlerin giderek güçlendiği ve teknolojik gelişmelerin hız kazandığı 20.yy'da dünya önemli değişimlerin yaşandığı bir döneme girmiştir. Bu dönemde ortaya çıkan globalleşme dünyanın ekonomik, teknolojik ve kültürel yapısı değişim sürecindeki yerini almıştır. Söz konusu değişime paralel olarak üretim, pazar olanakları, işbirlikleri, tüketim anlayışları da değişme uğramaktadır. Bu süreçte işletmeler sınırları ve kültürleri aşarak küresel ölçekte meydana gelen talebi karşılama çabası içine girmiştir.

Globalleşme süreci kendi olağan dinamikleri ile ortaya çıkan bir olgu olduğu kadar süreçte itici güç görevini gören bir takım faktörlerde bulunmaktadır. Buna göre (Aşıkoğlu, 1993: 15):

\section{A. Teknolojik Gelişmeler}

1980 yılından sonraki süreçte hız kazanan teknolojik gelişmeler globalleşmenin alt yapısını oluşturmuştur. Bilhassa bilgi ve iletişim alanında yaşanan gelişmeler ulaşım ve haberleşme maliyetini azaltarak, işlemlerin yapılmasında yer, zaman gibi kavramların önemini azaltmıştır. Bu sayede uluslararası finansal işlemlerin günün her anı yapılmasının önü açılmıştır. Görsel iletişim araçlarındaki gelişmeler ürün veya hizmetin reklamının yapılmasını kolaylaştırmış, ulusal ölçekteki tüketicinin yeni veya mevcut ürün hakkında bilgi sahibi olması kolaylaşmıştır (Baker, t.y.: 33-35). Bu anlamda temelde teknolojik özelde iletişim alanında yaşanan gelişmeler, pazarların yapısını, rekabetin biçimini ve finansal piyasaları doğrudan etkilemiştir. Günümüz şartlarında olduğu gibi teknolojik gelişmeler ve donanım ulusların rekabet gücünü belirleyen bir faktör olarak ortaya çıkmıştır (Eser, 1995: 17). Diğer taraftan teknolojik gelişmeler iletişimini yaygınlaştırıp hızlandırmakta bu sayede toplumların bir anlamda kültürlerin birbiri ile bütünleşmesine olanak tanımaktadır. Bu bağlamda teknolojinin globalleşme sürecinin önemli bir dinamiğini oluşturduğunu söylemek mümkündür.

\section{B. Rekabetin Yoğunlaşması}

Globalleşmenin ortaya çıkmasına neden olan en önemli faktörlerden biri rekabet alanında yaşanan yoğunlaşmadır. Rekabetin yoğunlaşması bir yandan globalleşmeyi ortaya çıkaran bir dinamik olarak kabul görürken bir yandan da globalleşmenin bir sonucu olarak kabul edilmektedir (Aşıkoğlu, 1993: 17). Teknolojik gelişmeler ile yaygınlaşan otomasyon dünyayı tek bir pazar haline dönüştürmüştür. Ülkeler arasındaki liberalleşme politikaları ve uluslararası ticarette yaşanan gelişmeler ile birlikte artan işletme sayısı nedeniyle günümüzde yoğun rekabet sadece işletmeleri değil ulusları da tehdit eden bir hale gelmiştir.

Rekabette yaşanan gelişmeler işletmelerin pazar paylarını ve satışlarını arttırmak adına çeşitli yollara başvurmasına neden olmaktadır. Bilhassa tüketici istek ve beklentilerinde oluşan farklılaşmaları tespit ederek o doğrultuda ürünler üretmek ve pazara sunmak en sık başvurulan yöntem olmuştur. Bu sayede işletme avantaj yakalamayı amaçlamaktadır (Bolt 1989: 34 41). Bu noktada "iletişim teknolojisi, teknolojik verimlilik, kalite işbirliği, insan gücü ve finansal kaynakların yeterliliği" olan global rekabetin kritik unsurları ortaya çıkmaktadır. Yoğun rekabet ortamında işletmeler ya ölçek ekonomileri uygulayarak ya da ortaklıklar ve işbirliği yoluna giderek dünya piyasalarına girmeye çalışmaktadır. Öncelikle işletme ürün maliyetini düşürme yoluna giderek ölçek ekonomisinden yararlanma yolunu seçmektedir. Global düzeye ulaşamamış ve birbiri ile rekabet halinde işletmeler ise güçlerini birleştirerek yeni pazarlara girmeye çalışmaktadırlar.

Globalleşme sürecinde, işletmelerin tamamı ölçekleri fark etmeksizin global rekabetin kritik ölçeklerini ortaya koyarak bu unsuralar bağlamında yönetim biçimlerini geliştirerek uygulamak zorunluluğundadır (Hitt, 2000: 7). Dolayısıyla rekabetin yoğunlaşması globalleşme sürecinin itici gücünü oluşturmaktadır.

\section{Dünya Ticaretindeki Gelişmeler}

Üretim globalleşmesi çok uluslu işletmelerin doğrudan yatırım yapmasının önem arz etmesi ve dünya ticaretindeki hızlı gelişme süreciyle ilişkilidir. Çok uluslu işletmeler II. Dünya savaşı sonrasındaki dönemde Batı Avrupa'da ABD yatırımlarının öncülüğünü yapan kuruluşlardır. Söz konusu dönemden sonraki süreçte önemi fark edilen çok uluslu işletmeler zaman içinde sanayileşmiş diğer ülkelerde görülmeye başlamıştır. Ayrıca üretimin ulusallaşmasındaki önemli görevi çok uluslu işletmeler yerine getirmektedir (Ongun, t.y.: 37). Bu bağlamda Dünya ticaretinde meydana gelen hızlı gelişmeler hem çok uluslu işletmeleri hem de uluslararası finans piyasasının önemi arttırmıştır.

\section{Pazarlama Homojenleri}

Globalleşme sürecinde dünya ticaretinde yeni pazarların bulunması, yatırımların etkinliğinin artırıması ve yatırımların verimli olması temel hedef olarak belirlenmiştir. Söz konusu yeni pazar kavramı değişen tüketici gereksinimleri, istekleri ve 
beklentileri doğrultusunda yeni ürünlerin bulunması ve pazara sürülmesi ifade edilmektedir (Finansal forum, 1997: 8). bireyin refah düzeyinin artması ve zenginleşmesi sonucunda harcanabilir gelirinin artması global ürünlerin pazara sunulmasını ve satışını kolaylaştırmaktadır. Dolayısıyla harcanabilir gelirdeki artış global ürünler için pazara oluşumunu desteklemektedir (Levitt, 1991: 14).

Dünya pazarındaki birçok ürün, sanayi ve pazar yapısı tüketici tercihi açısından birbiri ile benzerlik göstermektedir. Zira bu durumun ortaya çıkması için sermayenin gücü ve kitle iletişim araçları kullanılarak dünyadaki toplumlara ortak bir kültür değeri benimsetilmeye çalışılmaktadır. Bu sayede dünyadaki tüketicilerin istek ve ürün tercihleri homojen bir yapıya dönüştürülmektedir.

\section{E. Sermaye Dolaşımının Önümüzdeki Engellerin Kaldırılması}

Globalleşmenin diğer bir dinamiği ise, II. Dünya savaşından sonraki süreçte hızla gelişen finansal liberalleşme olarak da ifade edilen sermeyenin önündeki engellerin kaldııımasına yönelik çalışmalardır. Finansal serbestleşme devletlerin finans piyasaları üzerindeki denetim ve kısıtlamaları ortadan kaldırdığı veya hafiflettiği uyguları sonucunda ortaya çıkmaktadır. Liberalleşmeye karşı eğilimin artışı ve serbest piyasa ekonomisinin giderek daha fazla benimsenmesi, dış ticaret ve sermaye hareketleri üzerindeki denetimin ve kısıtlamaların ortadan kaldırılmasına ortam hazırlamıştır. Liberalleşme faaliyetlerinin artmasında devlet politikaları kadar uluslararası kuruluşlarda önemli rol üstlenmiştir. Gümrük tarifeleri ve hükümet politikaları birçok ülkenin dış ticaret üzerindeki denetim ve kısıtlamalarını kaldırmasının önünü açmıştır. Bu sayede sermayenin önündeki engeller kalkarak globalleşme ivme kazanmıştır (Can Aktan ve Şen, 1999: 15).

\section{LITERATÜRE INCELEMESI}

\section{Globalleşmeyi Ortaya Çıkaran Nedenler}

Liberal eğilimlerin giderek güçlendiği ve teknolojik gelişmelerin hız kazandığı 20.yy'da dünya önemli değişimlerin yaşandığı bir döneme girmiştir. Bu dönemde ortaya çıkan globalleşme dünyanın ekonomik, teknolojik ve kültürel yapısı değişim sürecindeki yerini almıştır. Söz konusu değişime paralel olarak üretim, pazar olanakları, işbirlikleri, tüketim anlayışları da değişme uğramaktadır. Bu süreçte işletmeler sınırları ve kültürleri aşarak küresel ölçekte meydana gelen talebi karşılama çabası içine girmiştir.

Globalleşme süreci kendi olağan dinamikleri ile ortaya çıkan bir olgu olduğu kadar süreçte itici güç görevini gören bir takım faktörlerde bulunmaktadır. Buna göre (Aşıkoğlu, 1993: 15):

\section{A. Teknolojik Gelişmeler}

1980 yılından sonraki süreçte hız kazanan teknolojik gelişmeler globalleşmenin alt yapısını oluşturmuştur. Bilhassa bilgi ve iletişim alanında yaşanan gelişmeler ulaşım ve haberleşme maliyetini azaltarak, işlemlerin yapılmasında yer, zaman gibi kavramların önemini azaltmıştır. Bu sayede uluslararası finansal işlemlerin günün her anı yapılmasının önü açılmıştır. Görsel iletişim araçlarındaki gelişmeler ürün veya hizmetin reklamının yapılmasını kolaylaştırmış, ulusal ölçekteki tüketicinin yeni veya mevcut ürün hakkında bilgi sahibi olması kolaylaşmıştır (Baker, t.y.: 33-35). Bu anlamda temelde teknolojik özelde iletişim alanında yaşanan gelişmeler, pazarların yapısını, rekabetin biçimini ve finansal piyasaları doğrudan etkilemiştir. Günümüz şartlarında olduğu gibi teknolojik gelişmeler ve donanım ulusların rekabet gücünü belirleyen bir faktör olarak ortaya çıkmıştır (Eser, 1995: 17). Diğer taraftan teknolojik gelişmeler iletişimini yaygınlaştırıp hızlandırmakta bu sayede toplumların bir anlamda kültürlerin birbiri ile bütünleşmesine olanak tanımaktadır. Bu bağlamda teknolojinin globalleşme sürecinin önemli bir dinamiğini oluşturduğunu söylemek mümkündür.

\section{B. Rekabetin Yoğunlaşması}

Globalleşmenin ortaya çıkmasına neden olan en önemli faktörlerden biri rekabet alanında yaşanan yoğunlaşmadır. Rekabetin yoğunlaşması bir yandan globalleşmeyi ortaya çıkaran bir dinamik olarak kabul görürken bir yandan da globalleşmenin bir sonucu olarak kabul edilmektedir (Aşıkoğlu, 1993: 17). Teknolojik gelişmeler ile yaygınlaşan otomasyon dünyayı tek bir pazar haline dönüştürmüştür. Ülkeler arasındaki liberalleşme politikaları ve uluslararası ticarette yaşanan gelişmeler ile birlikte artan işletme sayısı nedeniyle günümüzde yoğun rekabet sadece işletmeleri değil ulusları da tehdit eden bir hale gelmiştir.

Rekabette yaşanan gelişmeler işletmelerin pazar paylarını ve satışlarını arttırmak adına çeşitli yollara başvurmasına neden olmaktadır. Bilhassa tüketici istek ve beklentilerinde oluşan farklılaşmaları tespit ederek o doğrultuda ürünler üretmek ve pazara sunmak en sık başvurulan yöntem olmuştur. Bu sayede işletme avantaj yakalamayı amaçlamaktadır (Bolt 1989: 34 41). Bu noktada "iletişim teknolojisi, teknolojik verimlilik, kalite işbirliği, insan gücü ve finansal kaynakların yeterliliği" olan global rekabetin kritik unsurları ortaya çıkmaktadır. Yoğun rekabet ortamında işletmeler ya ölçek ekonomileri uygulayarak ya da ortaklıklar ve işbirliği yoluna giderek dünya piyasalarına girmeye çalışmaktadır. Öncelikle işletme ürün maliyetini 
düşürme yoluna giderek ölçek ekonomisinden yararlanma yolunu seçmektedir. Global düzeye ulaşamamış ve birbiri ile rekabet halinde işletmeler ise güçlerini birleştirerek yeni pazarlara girmeye çalışmaktadırlar.

Globalleşme sürecinde, işletmelerin tamamı ölçekleri fark etmeksizin global rekabetin kritik ölçeklerini ortaya koyarak bu unsuralar bağlamında yönetim biçimlerini geliştirerek uygulamak zorunluluğundadır (Hitt, 2000: 7).

\section{Global Finansal Yönetim Anlayışının Ortaya Çıkması}

Finansal yönetim, bilgi ve iletişim teknolojilerinin gelişmesiyle işletmelerin finansal piyasalardan yaralanabilmesi ve yeni finansman tekniklerinin etkin bir şekilde kullanabilmesi açısından büyük önem arz etmeye başlamıştır. Globalleşme süreciyle beraber teknolojik ve ticari alandaki gelişmeler finansman alanını da etkilemiştir. Bu anlamda finansal piyasalar ve finansman tekniklerinde önemli değişimlerin ve yeni tekniklerin önünü açılmıştır.

İşletmelerin sürekli bir büyüme eğilimi içinde olması, fon kaynaklarının sınırlı oluşu ve fon maliyetlerinin artması, dışa açık büyüme modellerinin seçilmesi gibi faktörler finansal piyasaların gelişmesinde son derece etkili olmuştur. Zira son yıllarda gelişme gösteren piyasa ve ülkelerin finansal piyasalardan daha fazla fon talep etmesi özellikle ticaret ve ekonomide olmak üzere rekabeti fazlalaştırarak finans piyasalarının ve finansal tekniklerin gelişmesine zemin hazırlamıştır.

Globalleşme süreci paralelinde Türkiye 1980 'lı yıllardan sonraki süreçte finansal piyasalar gelişim sürecine girmiştir. Gelişim süreci içinde yeni finansman teknikleri ve türev piyasaları Türkiye'de yer edinmeye başlamıştır.

\section{A. Finansal Yönetimin Globalleşme Süreci}

Globalleşeme süreci küçük veya büyük ölçekli işletme fark etmeksizin etkisi altına almaktadır. Etki sürecinde işletmenin en fazla etkilendiği fonksiyon şüphesiz finansal fonksiyonudur. Bu nedenle son yıllarda yapılan çalışmalar ile gelinen noktada, işletmenin rekabet ortamında varlığını sürdürmek ve hayatını idame ettirebilmek adına global stratejiler geliştirmesi zorunluluğu ortaya çıkmıştır. İşletmenin geliştirdiği stratejilerin değerlendirilmesi başta işletme içi sektör bazında olmak üzere çok yönlü olarak ele alınması gerekmektedir (Aşıkoğlu, 1993: 28-33).

Globalleşme sürecinin işletme üzerindeki etkisi çeşitli teoriler bağlamında açıklanmaya; değerlendirmelere uygun olarak çözüm önerileri geliştirilmeye çalışılmaktadır. Finansal yönetim anlayışının globalleşme süreci üç aşamalı bir süreçten geçmektedir: Ulusal finansal yönetim, uluslararası finansal yönetim, global finansal yönetim.

1.Ulusal Finansal Yönetim: Ulusal finansal yönetim eylemleri salt tek ülke şartları altında şekillenen finansal piyasalar ve kurumlar ile sınırlı bir durumdadır. Diğer bir ifade ile ulusal finansal yönetim olayı kabul edilen finansal planlama, fon sağlama, yatırım kararları ve fon kullanımı tek bir ülkenin kuralları ve sınırları dahilinde gerçekleşmektedir. Dolayısıyla finansal faaliyetler ülkenin finansal piyasasının boyutları ile sınırlı durumdadır. Bu noktada ülkenin piyasasının ölçeği ve etkinliği doğrultusunda işletmeler finansal faaliyetlerini yürütmektedir. Bu noktada sabit varlıkların, çalışma sermayesinin ve yatırım finansmanında ülkenin sahip olduğu para ve sermaye piyasasının imkânlarından yararlanmak durumundadır. Diğer taraftan ulusal sınırlar dahilinde oluşan finansal piyasada, sermaye piyasasında işlem gören menkul kıymetlerin pazar alanı da aynı şekilde ülke sınırları ile sınırlı durumdadır. Dolayısıyla ulusal finansal piyasa da işlem gören para birimi de ulusal para birimidir.

2.Uluslararası Finansal Yönetim: Ulusal işletmelerin uyduğu ilkeler açısından farklılık göstermeyen uluslararası finansal yönetim, söz konusu ilkelerin uygulanmasındaki amaç ve kapsam bakımında daha karmaşık ve dinamik bir niteliğe sahiptir. Bu bakımdan uluslararası iş dünyasıyla etkileşim içinde olan bir işletmenin, ülke sınırları dışındaki konjonktürel hareketlerden, döviz kurlarındaki hareketlilikten etkilenememesi söz konusu değildir. Dolayısıyla finans yöneticilerin işletmenin finansal riskine minimum düzeye indirgemesi hayatı önem taşımaktadır.

Uluslararası finansal yönetim işletmelerin dünya ülkelerinden hammadde alması ve üretimini dünya pazarına sunması sonucunda ortaya çıkmıştır. İşletmenin dış ülkelere ürün ihraç etmesi veya iş ortaklığı ile üretim gerçekleştirmesi gibi durumlarda finansal yönetim farklı bir boyuta taşınmaktadır. Bu noktada birden fazla para birimi, sermaye piyasası ve söz konusu para birimlerinin birbiri ile ilişkisini ortaya çıkarmaktadır (Eiteman t.y.: 3-7). Farklı ülkelerin para ve sermaye piyasalarındaki karşılıklı etkileşim sonucunda uluslararası finansal piyasalar ortaya çıkmaktadır. diğer bir ifade ile uluslararası işlemler ihracat bağlamında akreditif işlemler ile başlamakta; factoring, forfaiting, leasing, future ve opsiyon piyasalarında swap, hedging ve franching teknikleri ile gelişmektedir. Uluslararası sermaye akımı uluslararası finansal yönetim açısından büyük önem arz eden fon hareketleri, dış ticaretteki peşin ödemelerden uzun vadeli kredi hareketlerine, işletmeler arasındaki ödemelerden devletler arasındaki ödemelere kadar geniş bir süreci kapsamaktadır. Bahis geçen bu fon akışı ülkelerin ekonomik ihtiyaçlarına göre yön değiştirebilmektedir.

Sonuç olarak uluslararası piyasalarda faaliyet gösteren veya göstermeyi hedefleyen işletmeler açısından uluslararası finans yönetimi büyük önem arz etmektedir. Globalleşme sürecinin etki alanın genişlemesi finans yöneticilerin uluslararası finans piyasalarını yakından tanımalarını gerekli kılmaktadır. Bu sayede global düzeyde başarı kazanılabilecektir. 
3.Global Finansal Yönetim : Gerek ulusal düzeyde gerekse uluslararası düzeyde faaliyet gösteren işletmenin nihai amacı hissedarlara kar sağlamaktır. Uluslararası finansal yönetimde iki veya daha fazla ülkenin finansal piyasaları, söz konusu ülkede faaliyette bulunan işletmelerin finansal işlemlerini oluşturmaktadır. Bu bağlamda uluslararası piyasa bir kaç ülkenin finansal işlemlerinin görüldüğü sınırlı boyuttaki piyasa iken; global finansal piyasa ve yönetimi dünya genelini kapsayan bir boyuttadır (Aşıkoğlu, 1993: 28).

İşleme faaliyetlerinin global düzeyde gerçekleşmesi global finansal işlemleri ortaya çıkarmıştır. Dolayısıyla global ölçekte faaliyet gösteren işletmelerin dünya genelinde finansal piyasaları incelemeleri zorunluluğu ortaya çıkacaktır. Bu duruma bağlı olarak da finansal işlemler ortaya çıkmaktadır. Globalleşme sürecinin etkisi ile işletmeler ulusal ve uluslararası piyasaların ötesinde global ölçekteki piyasaları ve bu piyasalarda meydana gelen gelişmeleri takip etme zorunluluğu içine girmiş̧ir.

Global işletmelerin finansal yönetim faaliyetlerini dünya ölçeğinde programlaması, planlaması, uygulaması, koordine etmesi global yönetim anlayışı için zorunlu bir yaklaşımdır. Global finansal yönetimde fonların oluşturulması korunması ve etkinliğinin sağlanması için uygulanan sistemin denetim ve kontrol ilkeleri dünya standartlarında olması gerekmektedir (Aşıkoğlu, 1993: 30-31). Zira global ölçekli piyasalarda bir kaç ülkenin piyasa etkileşiminde ziyada dünya ülkelerinin etkileşimi söz konusudur. Bu nedenle denetimlerin birkaç ülke ilkelerine göre değil dünya genelinde kabul görmüş ilkelere göre yapılması doğru bir yaklaşım olacaktır.

\section{B. Finansal Piyasalarının Globalleşmesi}

Bilişim ve iletişim alanında yaşanan teknolojik gelişmeler finansal piyasaların ulusallaşmasında önemli bir etken olmuştur. Uluslararası piyasalarda meydana gelen başarı, hisse senedi fiyatlarındaki artışın teknolojik gelişmeler sayesinde anında haberdar olunmasından kaynaklanmaktadır. Diğer taraftan dünyanın farklı yerlerinde bulunan yatırımcıların günün her anı alışveriş yapabilmesi teknolojik gelişmeler ile mümkün hale gelmiştir. Ayrıca uluslararası iletişimi düşük maliyetli oluşu yatırımcının veya tüketicinin ülke dışında yatırım yapmasının önünü açmıştır.

Günümüz şartlarında dünyadaki piyasaların tamamı bütünleşme süreci içine girmiştir. Bu süreçte bilgi teknolojisinde meydana gelen gelişmeler ve bireysel ölçekteki girişimcilik faaliyetleri de önemli rol oynamaktadır. Sermeye piyasalarının gelişmesi ile mali işlem hacminin büyümesi ve çeşitlenmesi, finansal araçların türünün ve tekniklerinin gelişmesi global piyasaların karakteristik nitelikler olarak öne çıkmaktadır. Bu durum sermaye piyasalarının globalleşmesi olarak da ifade edilebilmektedir.

1.Uluslararası Finansal işlemlerinin Artması: Uluslararası finansal piyasalar, farklı sebeplere bağlı olarak devletlerin kendi sınırları dışındaki piyasalardan finansman sağlamayı amaçlayan devlet veya şirketlerle, yine kendi ülke sınırları dışında tasarruflarını çeşitli nedenlerle kurum veya kuruluşlara kullandıran kişi veya kuruluşların bir araya gelerek oluşturdukları piyasalar şeklinde ifade etmek mümkündür (Akyüz, 1993: 11).

Uluslararası finansal merkezlerin temel işlevleri, finansal fonların arz edenlerden gereksinim sahiplerine en etkin şekilde geçişinin sağlanması şeklinde ifade etmek mümkündür. Bahsedilen şekilde fon arayışı içinde olanlar uluslararası finansal pazarlardan talebini karşılamaktadır. Ayrıca elinde fazla fon bulunan yatırımcılar uluslararası finans piyasalarına yönelerek karlı işlemler gerçekleştirebilmektedirler. Dolayısıyla uluslararası finansal işlemlere bireysel ve kurumsal yatırımcılar perspektifinden bakıldığında, uluslararası yatırımların yüksek gelir elde etme veya riski ortadan kaldırma gibi sebeplere bağlı olarak yapıldığı görülmektedir (Aşıkoğlu, 1993: 58-67).

Globalleşmenin ağırık kazanmaya başladığı 1980’ı yıllardan günümüze kadar olan dönemde, finansal piyasalar hızlı bir değişim süreci yaşamıştır. Uluslararası işlemler, yatırımcıların finansman maliyetini düşürmek, finansman sağlamak veya belirli bir düzenlemenin beraberinde getirdiği engelleri aşmak adına yürüttüğü faaliyetler sonucu ortaya çıkmaktadır. Söz konusu işlem türü globalleşme süreci ile hızlanarak her geçen zamanda işlem türü, hacmi ve araçları artış göstermektedir.

2.Uluslararası Yeni Fon Kaynakları: İşletmelerin kullanabileceği iki tür fon kaynağından söz etmek mümkündür: işlemenin kendi bünyesinde yarattığı nakit fon ve kısa ve uzun vadeli işletme dışı fonladır. Söz konusu kaynaklarda genel anlamda hisse senedi ihracı veya tahvil çıkarımı şeklindedir. Finans piyasalarında gerçekleşen gelişmeler ile finans piyasaları ve finans kuruluşları hakkında bilgi edinme sürecinin kolaylaşması finans yöneticilerinin fon kaynakları sayısını artırmıştır. Bu açıdan bakıldığında finans yöneticilerinin fon kaynakları ulusal piyasalar ile sınırlı kalmamakta, her hangi sermaye piyasasından uygun finans koşullarında anında yararlanma olanağına kavuşmuştur. Ayrıca söz konusu gelişmeler finans kurumları dışında ticaret ve sanayi kurumlarının da finans kurumlarının aracılığına gerek duymaksızın gelişmiş ekonomik piyasalarda yatırım yapma veya fon bulabilme imkânı yakalamıştır. Yerli yatırımcıların yerli fon talebinde bulunanlara fon sağlaması şeklinde işlemler ülke sınırları içi niteliktedir ve uluslararası bir yönü bulunmamaktadır. Lakin ulusal fonların yabancılara veya yabancı fonların yerli kullanıcıya fon sağlaması durumunda işlem uluslararası bir nitelik kazanmaktadır (Gallo ve Lockwood, 1999: 44). 
Sonuç olarak finansal yenilikler işletmelerin önceden ulaşmadıkları kaynaklara ulaşmalarına, yatırımcı ve ödünç alıcıların çeşitlenmesi ile risk minimum seviyeye indirilmektedir.

3.Uluslararası Yeni Yatırım Olanakları: Globalleşmenin getirdiği yenilikleri ile birlikte uluslararası yatırım farklı bir boyuta taşınmıştır. Ortaya çıkan yeni teknikler, araçlar ve türevleri yatırımcıların hizmetine sunulmuştur. Günümüz şartlarında yatırımcılar uluslararası yatırımlar yaparak risk çeşitlendirmesi yoluna gitmektedir. Yerli yatırımcıların, yabancı tahvil, hisse senedi gibi yatırım araçları ile doğrudan dış yatırım yapması kolaylaşmıştır. Söz konusu gelişmeler dahilinde yabancı işletmeler hisse senetlerini tasarrufçu ana ülkenin borsalarında kaydettirmektedir (Seyidoğlu, 1994: 248).

Devletlerin finansal serbestleşme yolunda çalışmalarına rağmen, sermayenin dolaşımı ve ulusal sınırların dışına çıkarılması konusunda devletlerin müdahalesi halen söz konusudur. Bu noktada teoride uluslararası piyasa işlemleri ile sermaye maliyetlerini azaltmak mümkün iken uygulamada bir takım problemler ortaya çıkmaktadır (Aşıkoğlu, 1993: 67). Söz konusu devlet müdahaleleri ve sınırlamalar uluslararası piyasalarda fon aktarımının zorlaşmasına neden olduğundan sermaye maliyetini yükseltmekte ve yatırımcıların da çekimser davranmasına neden olmaktadır.

4.Elektronik Bankacılık: Elektronik bankacılığın en önemli ürünü olan elektronik fon transferi (EFT) uygulaması ile bankacılık işlemleri hız kazanmıştır. EFT geleneksel bankacılıkta olduğu gibi fonun bir yerden başka bir yere transferini ifade etmektedir. Temelde aynı işlem olmasına rağmen işlemlerde büyük kolaylık sağladığından zaman kavramının iyi kullanılmasına olanak tanımaktadır.

Elektronik bankacılık bankaların, kendi hesabına veya müşteri hesabına farklı finans merkezlerinden kur farklılığını dikkate alarak hisse senedi, tahvil ve döviz gibi finansal varlıkların alım ve satımın işlemlerinde kolaylık sağlamaktadır. Dolayısıyla hızla gelişen iletişim ve işlem teknolojisinin işlem maliyetlerini azaltması finans piyasalarındaki gelişmenin itici gücünü oluşturduğunu görülmektedir. Diğer taraftan bilgisayar teknolojisinde yaşanan gelişmeler uluslararası fonların anında ve kolayca transferini kolaylaştırdığından fon hareketliliği hızlanmıştır.

5.Euro'ya Geçiş: Her ülkenin kendine özgü bir para birimi bulunmaktadır. Lakin 1 Ocak 1999 tarihi itibari ile Avrupa ülkeleri kendilerine has para birimlerini Euro olarak değiştirme kararı almıştır. Bu noktada globalleşme süreci milli bir değer olan para biriminin de değişimine sebebiyet vermiştir. Avrupa devletleri ortak para birimi olarak kabul et Euro, bankalar, sigorta kurumları, borsalar ve devlet işlemlerinde zorunlu tüketici ve işlemler düzeyinde isteğe bağlı olarak tedavüle çıkmıştır. Dolayısıyla Avrupa birliğine üye ülkelerin merkez bankaları yetkilerini Avrupa merkez bankasına devretmişlerdir. Ortak para birimine geçiş globalleşmenin getirdiği en önemli değişikliklerden biri olarak kabul edilmesinin yanında uluslararası piyasalarda da meydana gelen önemli bir değişiklik olarak kabul görmektedir. Bu noktada Birliğin uyguladığı ekonomik politikalar ekonomik ilişki içinde olduğu ülkeleri de doğrudan etkilemektedir.

\section{SONUÇ}

Teknolojik ve bilimsel gelişmelere endeksli olan globalleşme birçok alanda olduğu gibi ekonomi alanında da radikal değişimleri beraberinde getirmiştir. Globalleşme sürecinde ulusal ve uluslararası ekonomi piyasalarında yeni eğilimler ortaya çıkmaktadır. Ekonomi piyasalarında meydana gelen yeni eğilimler en çok işletmeleri etkilemiştir.

Globalleşme sürecinin etkisini her geçen gün arttırdığı düşünüldüğünde işletmelerin yoğun rekabet ve etkileşim ortamında sürecin karşısında durarak, kapalı bir ekonomik yapı sürdürmek isteyen işletmeler kendilerini ekonomik hayatın da dışına atmayı kabul etmiş sayılmaktadırlar. Bu noktada globalleşme sürecinde başarılı olmayı hedefleyen işletmelerin finansal alandaki yeni teknik ve yaklaşımları uygulamaları büyük önem taşımaktadır. Zira yeni eğilimler finansal globalleşme kavramını ve kurallarını beraberinde getirmiştir. Dinamik yapıdaki ekonomilerin sürece adapte olması rekabet ortamında ulusal ve uluslararası işletmelerinde yeni eğilimlere adaptasyonunu gerekli kılmıştır.

İşletmelerin açık bir sisteme sahip olmaları nedeniyle globalleşme işletme fonksiyonlarının tamamını etkilemektedir. Diğer taraftan işletmenin aldığı kararlarının büyük kısmının finansal nitelikte olması finans fonksiyonunu daha faza etkilemesine neden olmaktadır. Bu nedenle işletme fonksiyonlarının finans yönelimli bir şekilde bütüncül olarak ele alınması gerekmektedir. Bu durumun sağlanması içinde etkin finansal yönetim uygulamalarının hayata geçirilmesi gerekmektedir

\section{KAYNAKLAR}

Akyüz, Ab. (1993). “ Uluslararası Finanasal Piyasalar Ve Türkiye” İşletme Ve Finans, Haziran, S. 87.

Aşıkoğlu, R. (1993). Globalleşme Sürecinde Uluslararası Finansal Yönetimler, Dumlupınar Üniversitesi Iktisadi Ve İdari Bilimler Fakültesi Yayınları No:2, Kütahya.

Baker, S. (t.y.). “Global E-Commerce, Local Problems” Journal Of Business Strategy, Jully Agust, 1999, Vol: 20, NO: 4, ss. 33-35

Bolt, J. (1989). “Global Competitions Some Kriterla For Succes" Busines Horizons, Vol.31, Feb, s. 34-41. 
Can Aktan, Ç. ve Şen, H. (1999). “Globalleşme, Ekonomik Kriz Ve Türkiye” TOSYÖV Ekonomik Sosyal Araştırmalar Serisi NO:1, Kasım, 1999. Çeken, H. (2003). Küreselleşme Yabancı Sermaye ve Türkiye Turizmi, Değişim Yayınları.

Dicle, A. (2000). "Küreselleşme: Nedenler, Sonuçlar, Tepkiler 1-2," Ekonomik Forum Dergisi, 2000.

Eiteman, D. S. (t.y.). Multinational Business Finance, Fourth USA.

Eser, U. (1995). “ Globalleşme Tehdit Mi? Yoksa Fırsat Mı?” Ekonomik Yaklaşım, C: 6, Yaz.

Finansal forum 30 haziran 1997.

Gallo J. ve Lockwood, L. (1999). "Fund Management Changes And Equity Style Shifts", Financial Analysts Journal, September/October. Hitt M. (2000). “Transfermation Of Management For The New Millennium” Organizational Dynamics Winter, 2000.

Kutal, G. (1996). Endüstri İlişkileri Boyutunda Çok Uluslu Şirketler ve İnsan Kaynağı Yönetimi teori ve Uygulama, İstanbul, Der Yayınları. Levitt, T. (1991). “Going Global: Succeeding İn Word Markets” Harvard Business Reviev, Paperback.

Ongun T. (t.y.). "Finansal Globalleşme" Ekonomik Yaklaşım, C:4, S.9.

Öymen, O. (2000). Geleceği Yakalamak, Remzi Kitabevi, i̇stanbul.

Seyidoğlu, H. (1994). Uluslararası Finans, Güzem Yayınları. 